Dhaka Univ. J. Biol. Sci. 30(1): 49-57, 2021 (January)

\title{
EFFECTS OF POULTRY LITTER COMPOST AND CHEMICAL FERTILIZERS ON GROWTH AND YIELD OF FIELD GROWN SUNFLOWER (HELIANTHUS ANNUS L.)
}

\author{
M Alauddin, GM Mohsin ${ }^{1}$, AHM ZulfiQuar Ali ANd MK RaHMAN \\ Department of Soil, Water and Environment, University of Dhaka, \\ Dhaka-1000, Bangladesh
}

Key words: Growth, Yield, NPK fertilizer, Poultry litter compost, Sunflower

\begin{abstract}
A field experiment was carried out in the research farm of Charfasson Govt. College, Bhola during Rabi season in 2016-2017 to evaluate the effects of poultry litter (PL) compost and NPK fertilizers on growth and yield of sunflower $c v$. BARI-2 (Keroni-2). Sixteen treatments were used with three replications each. Treatments were $\mathrm{T}_{1}$ : Control (-PL and $\left.-\mathrm{NPK}\right), \mathrm{T}_{2}: 1.5$ ton PL/ha, $\mathrm{T}_{3}: 3.0$ ton $\mathrm{PL} / \mathrm{ha}, \mathrm{T}_{4}: 4.5$ ton PL/ha, $\mathrm{T}_{5}: \mathrm{N}_{40} \mathrm{P}_{30} \mathrm{~K}_{50} \mathrm{~kg} / \mathrm{ha}, \mathrm{T}_{6}: \mathrm{N}_{80} \mathrm{P}_{60} \mathrm{~K}_{100} \mathrm{~kg} /$ ha, $\mathrm{T}_{7}: \mathrm{N}_{120} \mathrm{P}_{90} \mathrm{~K}_{150}$ $\mathrm{kg}$ /ha, $\mathrm{T}_{8}: 1.5$ ton PL/ha $+\mathrm{N}_{40} \mathrm{P}_{30} \mathrm{~K}_{50} \mathrm{~kg} / \mathrm{ha}, \mathrm{T}_{9}: 1.5$ ton PL/ha $+\mathrm{N}_{80} \mathrm{P}_{60} \mathrm{~K}_{100} \mathrm{~kg} / \mathrm{ha}, \mathrm{T}_{10}$ : 1.5 ton PL/ha $+\mathrm{N}_{120} \mathrm{P}_{90} \mathrm{~K}_{150} \mathrm{~kg} /$ ha, $\mathrm{T}_{11}: 3.0$ ton PL/ha $+\mathrm{N}_{40} \mathrm{P}_{30} \mathrm{~K}_{50} \mathrm{~kg} / \mathrm{ha}, \mathrm{T}_{12}: 3.0$ ton $\mathrm{PL} / \mathrm{ha}+\mathrm{N}_{80} \mathrm{P}_{60} \mathrm{~K}_{100} \mathrm{~kg} / \mathrm{ha}, \mathrm{T}_{13}: 3.0$ ton PL/ha $+\mathrm{N}_{120} \mathrm{P}_{90} \mathrm{~K}_{150} \mathrm{~kg} / \mathrm{ha}, \mathrm{T}_{14}: 4.5$ ton PL/ha + $\mathrm{N}_{40} \mathrm{P}_{30} \mathrm{~K}_{50} \mathrm{~kg}$ ha, $\mathrm{T}_{15}: 4.5$ ton PL/ha $+\mathrm{N}_{80} \mathrm{P}_{60} \mathrm{~K}_{100} \mathrm{~kg}$ ha and $\mathrm{T}_{16}: 4.5$ ton PL/ha + $\mathrm{N}_{120} \mathrm{P}_{90} \mathrm{~K}_{150} \mathrm{~kg}$ /ha. Plant height $(204.3 \mathrm{~cm})$, number of leaf (44.8/plant), leaf area (376.4 $\mathrm{cm}^{2}$ plant), leaf area index (13.61), dry weight of stem (61.57 g/plant), root (12.66 g/plant), leaf (21.47 g/plant), petiole $(8.7 \mathrm{~g} /$ plant $)$, total dry matter production (134.0 g/plant) were found highest in $\mathrm{T}_{16}$ treatment. On the contrary, dry weight of inflorescence (32.6 g/plant), dry weight of seed (44.4 g/plant) and number of seeds (663/plant) were found highest in $\mathrm{T}_{13}$ and $\mathrm{T}_{14}$ treatments, respectively. Higher dry weight of 100 seeds $(7.4 \mathrm{~g})$ and diameter of inflorescence $(54 \mathrm{~cm})$ were also found in $T_{13}$ treatment. Although highest value was found in $\mathrm{T}_{16}$ treatment, but $\mathrm{T}_{16}$ and $\mathrm{T}_{13}$ were not significantly $(\mathrm{p}>0.05)$ different, it can be treated as best $\left(\mathrm{T}_{13}\right)$ for future trial. The overall findings of this study indicated that organic fertilizer (poultry litter) in combination with inorganic fertilizers may be a good indicator to achieve better agronomic and yield parameters of sunflower plants under southern coastal edaphic conditions of Bangladesh.
\end{abstract}

\section{Introduction}

Sunflower (Helianthus annus L.) is one of the most common oil crops widely grown in different parts of the world. Globally, sunflower ranks second next to soybean among annual field crops grown for edible oil ${ }^{(1)}$. Sunflower has gained popularity of all the

*Author for correspondence: <abuhena66@gmail.com>. ${ }^{1}$ Department of Agriculture, Noakhali Science and Technology University, Noakhali-3814, Bangladesh.

DOI: https://doi.org/10.3329/dujbs.v30i1.51808 
oilseed crops because of its excellent quality oil due to its richness with high degree polyunsaturated fatty acids, anti-cholesterol properties, short duration, wide adaptability to soil and climatic conditions, photo and thermo-insensitiveness, drought tolerance and higher oil yield per unit area. The quantity of sunflower oil represents about $15 \%$ of the total world production of the major vegetable oils.

Sunflower seed contains a high percentage of oil (40-50\%) and rich in protein 26 per cent (2). Sunflower oil is considered as premium oil because of its light color, flavor and this oil is unsaturated with high levels of linoleic acid. High percentage poly-unsaturated fatty acids in sunflower oil such as linoleic acid in classical sunflower, which can reach up to $90 \%$ of the total unsaturated fatty acids, makes it high-quality edible oil commercially ${ }^{(1)}$. Its seed has a good percentage of crude fibre (16-27), ash (2-3), soluble sugar (7-9) and hull (21-27)(3).

Organic agriculture practices aim to enhance biodiversity, biological cycles and soil biological activity so as to achieve optimal natural systems that are socially, ecologically and economically sustainable ${ }^{(4)}$. The poultry industry is one of the largest and fasted growing agro-based industries in the world. This results the large-scale accumulation of wastes including manure and litters which may pose disposal and pollution unless environmentally and economically sustainable management technologies are evolved. Most of the litter produced by the poultry industry is currently applied to agricultural land as a source of nutrients and soil amendment ${ }^{(5)}$.

Poultry manure is an excellent organic manure as it contains high N, P, K and other essential nutrients. It has been reported to supply $\mathrm{P}$ more readily to plants than other organic sources. Poultry manure increased soil $\mathrm{pH}$, organic matter content, available $\mathrm{P}$, exchangeable cations and micronutrients, and decreased exchangeable $\mathrm{Al}$ and $\mathrm{Fe}$ contents and soil bulk density ${ }^{(6)}$. Poultry manure application increased soil $\mathrm{N}$ levels by $53 \%$ while exchangeable cations contents also increased appreciably. Soil $\mathrm{N}$ and $\mathrm{P}$ contents have been shown to increase with increasing rates of poultry manures( ${ }^{(6)}$.

Now a days increase in the prices of chemical fertilizers, lack of consistency in feeding the soil and endangering human health cause to the increase of the use of manure for soil fertility(6). Excessive nitrogen fertilization of sunflower not only generates that environmental risk, it may also affect the grain quality, decreasing its oil content and reduce yield through an increase of plant lodging $(4,7)$. On the other hand, manure can improve soil fertility, increase water holding capacity, decrease soil erosion, improves amount of oxygen, and promotes beneficial organisms and productivity(7). Organic sources such as animal manure, poultry litter, rice bran, vermicompost, farmyard manure, sawdust could be a beneficial source of major nutrient when was applied at optimum rates and can influence the temporal dynamics of nutrient availability through their effects on physical and chemical properties of soil(7).

Sunflower plant gave a higher yield from a combination of organic manures with chemical fertilizer ${ }^{(4)}$. For higher productivity and sustainability, integrated use of organic 
and inorganic sources of nutrients is very important $t^{(8)}$. Therefore, a field experiment was carried out to evaluate the growth and yield performance of sunflower (Helianthus annus L.) as influenced by poultry litter compost and chemical fertilizers in the coastal region of Bangladesh.

\section{Materials and Methods}

A field study was carried out at the research farm of Charfasson Govt. College, Bhola, Bangladesh during Rabi season in 2016-2017. Soil samples (0-15 cm depth) were collected from the research farm. The sample was air dried, ground and sieved through 1 $\mathrm{mm}$ sieve for chemical analysis and $2 \mathrm{~mm}$ sieve for physical analysis and was kept in polyethylene bags.

The soil had found $\mathrm{pH}$ of $8.30\left(1: 2.5 \mathrm{w} / \mathrm{N} \mathrm{H}_{2} \mathrm{O}\right)$, organic carbon $0.85 \%$ (Wet oxidation method) ${ }^{(9)}$ available nitrogen $0.27 \%$ (Kjeldahl extraction method)(10), available phosphorus $0.09 \%(11)$, available potassium $1.33 \%$, available sulfur $0.13 \%$. Particle size distribution was determined by hydrometer method(12). The soil had sand $12.2 \%$, silt $51.34 \%$ and clay $36.46 \%$, textural class-silty clay loam. The maximum water retentive capacity was $40 \%$.

Seeds of sunflower were collected from BADC farm of Barisal. The variety of seed was BARI-2 (Keroni-2). The experiment was laid out in a completely randomized block design (CRBD) having sixteen treatments with three replications. Each plot size was $3 \mathrm{~m}$ x $2 \mathrm{~m}$. Treatments were $\mathrm{T}_{1}:$ Control (-PL and -NPK), T2: 1.5 ton PL/ha, $\mathrm{T}_{3}: 3.0$ ton PL/ha, $\mathrm{T}_{4}$ : 4.5 ton PL/ha, $\mathrm{T}_{5}: \mathrm{N}_{40} \mathrm{P}_{30} \mathrm{~K}_{50} \mathrm{~kg} /$ ha, $\mathrm{T}_{6}: \mathrm{N}_{80} \mathrm{P}_{60} \mathrm{~K}_{100} \mathrm{~kg}$ /ha, $\mathrm{T}_{7}: \mathrm{N}_{120} \mathrm{P}_{90} \mathrm{~K}_{150} \mathrm{~kg}$ /ha, T8: 1.5 ton $\mathrm{PL} / \mathrm{ha}+\mathrm{N}_{40} \mathrm{P}_{30} \mathrm{~K}_{50} \mathrm{~kg}$ /ha, $\mathrm{T} 9: 1.5$ ton PL/ha $+\mathrm{N}_{80} \mathrm{P}_{60} \mathrm{~K}_{100} \mathrm{~kg} /$ ha, $\mathrm{T}_{10}: 1.5$ ton PL/ha $+\mathrm{N}_{120} \mathrm{P}_{90} \mathrm{~K}_{150}$ $\mathrm{kg}$ ha, $\mathrm{T}_{11}: 3.0$ ton PL/ha $+\mathrm{N}_{40} \mathrm{P}_{30} \mathrm{~K}_{50} \mathrm{~kg} /$ ha, $\mathrm{T}_{12}: 3.0$ ton PL/ha $+\mathrm{N}_{80} \mathrm{P}_{60} \mathrm{~K}_{100} \mathrm{~kg}$ ha, $\mathrm{T}_{13}: 3.0$ ton $\mathrm{PL} / \mathrm{ha}+\mathrm{N}_{120} \mathrm{P}_{90} \mathrm{~K}_{150} \mathrm{~kg}$ /ha, $\mathrm{T}_{14}: 4.5$ ton PL/ha $+\mathrm{N}_{40} \mathrm{P}_{30} \mathrm{~K}_{50} \mathrm{~kg} /$ ha, $\mathrm{T}_{15}: 4.5$ ton PL/ha $+\mathrm{N}_{80} \mathrm{P}_{60} \mathrm{~K}_{100}$ $\mathrm{kg}$ ha and $\mathrm{T}_{16}$ : 4.5 ton PL/ha $+\mathrm{N}_{120} \mathrm{P}_{90} \mathrm{~K}_{150} \mathrm{~kg} / \mathrm{ha}$. The doses were selected according to BARC $^{(13)}$.

Poultry litter compost; N, P and K were applied after the final preparation of land. N, $\mathrm{P}$ and $\mathrm{K}$ were applied as urea, triple superphosphate and murate of potash, respectively. Sixty seeds were sown in each rows. Distance between row to row was $40 \mathrm{~cm}$ and between seed to seed $25 \mathrm{~cm}$. Intercultural practices i.e. weeding, spading, fencing, pesticide etc. were done accordingly. Different agronomic parameters viz. plant height, leaf number (with the help of a Taley counter), leaf area (length $\times$ width) and leaf area index (leaf area divided by ground area) were measured at the intervals of 30,60 and 90 Days After Sowing (DAS) of seeds. Finally, plants were harvested after 90 days of sowing of seeds at the period of maturity. Sunflower plants were harvested as root, stem, leaf, petiole and inflorescence of sunflower plant were measured. Plant samples were airdried and oven dried at temperature of $65^{\circ} \mathrm{C}$ for $72 \mathrm{~h}$. Dry weight of seed, diameter of inflorescence, number of seeds and weight of 100 seeds were measured and kept in paper bags separately. Statistical analysis was made using SPSS software. 


\section{Results and Discussion}

Plant height and leaf number: Effects of poultry litter compost and NPK fertilizers on the height and number of leaf/plant sunflower plants are shown in Table 1. The height and leaf number of sunflower plant were significantly $(\mathrm{p}<0.05)$ higher in the treatment of combined doses of fertilizer than the control treatment. At the early stage, significant $(p<0.05)$ differences were observed between individual treatments of organic or chemical fertilizers. With the increase in sowing time no differences were observed between these treatments individually, only difference observed between single organic or chemical and (chemical plus organic). Maximum height $(204.3 \mathrm{~cm}$ ) and leaf number (44.8 no. plant) are found in the treatment $\mathrm{T}_{16}\left(4.5\right.$ ton $\left.\mathrm{PL}+\mathrm{N}_{120} \mathrm{P}_{90} \mathrm{~K}_{150} \mathrm{~kg} / \mathrm{ha}\right)$. Although longest height was found in $\mathrm{T}_{16}$ treatment; this treatment is not significantly $(\mathrm{p}>0.05)$

Table 1. Influence of poultry litter and NPK fertilizers on height and leaf number/plant of sunflower plant.

\begin{tabular}{|c|c|c|c|c|c|c|}
\hline \multirow[t]{2}{*}{ Treatments } & \multicolumn{3}{|c|}{ Height $(\mathrm{cm})$} & \multicolumn{3}{|c|}{ Leaf number (No. of leaves/plant) } \\
\hline & 30 DAS & 60 DAS & 90 DAS & 30 DAS & 60 DAS & 90 DAS \\
\hline $\mathrm{T}_{1}$ : Control (-PL and -NPK) & $34.0^{\mathrm{a}}$ & $78.0^{\mathrm{a}}$ & $88.0^{\mathrm{a}}$ & $12.7^{\mathrm{a}}$ & $16.0^{\mathrm{a}}$ & $24.6^{\mathrm{a}}$ \\
\hline $\mathrm{T}_{2}: 1.5 \mathrm{t}$ ha PL (50\% RDF) & $48.0^{\mathrm{a}}$ & $112.0^{\mathrm{b}}$ & $118.2^{\mathrm{b}}$ & $15.7^{\mathrm{b}}$ & $20.7^{\mathrm{b}}$ & $30.4^{\mathrm{b}}$ \\
\hline $\mathrm{T}_{3}: 3 \mathrm{t}$ ha PL (100\% RDF) & $56.7^{\mathrm{b}}$ & $112.3^{\mathrm{b}}$ & $118.7^{b}$ & $13.3^{\mathrm{a}}$ & $20.0^{\mathrm{ab}}$ & $33.5^{\mathrm{b}}$ \\
\hline $\mathrm{T}_{4}: 4.5 \mathrm{t}$ ha PL (150\% RDF) & $46.0^{\mathrm{ab}}$ & $132.0^{\mathrm{b}}$ & $137.0^{\mathrm{b}}$ & $15.0^{\mathrm{b}}$ & $20.3^{\mathrm{ab}}$ & $35.7^{\mathrm{b}}$ \\
\hline $\mathrm{T}_{5}: \mathrm{N}_{40} \mathrm{P}_{30} \mathrm{~K}_{50} \mathrm{~kg}$ ha $(50 \% \mathrm{RDF})$ & $60.7^{b}$ & $132.7^{b}$ & $138.3^{b}$ & $15.7^{b}$ & $22.0^{\mathrm{b}}$ & $34.8^{\mathrm{b}}$ \\
\hline $\mathrm{T}_{6}: \mathrm{N}_{80} \mathrm{P}_{60} \mathrm{~K}_{100} \mathrm{~kg}$ ha $(100 \% \mathrm{RDF})$ & $68.3^{\mathrm{b}}$ & $140.7^{c}$ & $145.3^{c}$ & $16.3^{\mathrm{b}}$ & $24.3^{\mathrm{b}}$ & $38.6^{\mathrm{bc}}$ \\
\hline $\mathrm{T}_{7}: \mathrm{N}_{120} \mathrm{P}_{90} \mathrm{~K}_{150} \mathrm{~kg}$ ha $(150 \% \mathrm{RDF})$ & $85.0^{c}$ & $163.3^{\mathrm{d}}$ & $170.3^{\text {de }}$ & $18.3^{c}$ & $25.0^{\mathrm{b}}$ & $39.5^{\mathrm{bc}}$ \\
\hline $\mathrm{T}_{8}: 1.5 \mathrm{t}$ ha $\mathrm{PL}+\mathrm{N}_{40} \mathrm{P}_{30} \mathrm{~K}_{50} \mathrm{~kg}$ ha & $50.7^{\mathfrak{b}}$ & $160.7^{\mathrm{d}}$ & $174.7^{\mathrm{de}}$ & $16.0^{\mathrm{b}}$ & $27.3^{\mathrm{bc}}$ & $37.2^{\mathrm{bc}}$ \\
\hline $\mathrm{T}_{9}: 1.5 \mathrm{t} / \mathrm{ha} \mathrm{PL}+\mathrm{N}_{80} \mathrm{P}_{60} \mathrm{~K}_{100} \mathrm{~kg} / \mathrm{ha}$ & $59.0^{\mathrm{b}}$ & $175.3^{\mathrm{d}}$ & $182.8^{\mathrm{ef}}$ & $15.3^{\mathrm{b}}$ & $27.3^{\mathrm{bc}}$ & $39.7^{\mathrm{bc}}$ \\
\hline $\mathrm{T}_{10}: 1.5 \mathrm{t}$ /ha PL + $\mathrm{N}_{120} \mathrm{P}_{90} \mathrm{~K}_{150} \mathrm{~kg}$ /ha & $73.0^{c}$ & $173.7^{\mathrm{d}}$ & $185.0^{\text {ef }}$ & $16.3^{\mathrm{b}}$ & $27.3^{\mathrm{bc}}$ & $42.6^{\mathrm{bc}}$ \\
\hline $\mathrm{T}_{11}: 3 \mathrm{t} / \mathrm{ha} \mathrm{PL}+\mathrm{N}_{40} \mathrm{P}_{30} \mathrm{~K}_{50} \mathrm{~kg} / \mathrm{ha}$ & $64.3^{\mathrm{bc}}$ & $151.7^{c}$ & $168.0^{\text {de }}$ & $16.3^{\mathrm{b}}$ & $24.0^{\mathrm{b}}$ & $36.8^{\mathrm{bc}}$ \\
\hline $\mathrm{T}_{12}: 3 \mathrm{t} /$ ha $\mathrm{PL}+\mathrm{N}_{80} \mathrm{P}_{60} \mathrm{~K}_{100} \mathrm{~kg} / \mathrm{ha}$ & $67.0^{\mathrm{bc}}$ & $172.3^{\mathrm{d}}$ & $182.2^{\mathrm{de}}$ & $17.0^{\mathrm{bc}}$ & $23.7^{b}$ & $30.3^{\mathrm{b}}$ \\
\hline $\mathrm{T}_{13}: 3 \mathrm{t} / \mathrm{ha} \mathrm{PL}+\mathrm{N}_{120} \mathrm{P}_{90} \mathrm{~K}_{150} \mathrm{~kg}$ ha & $87.0^{c}$ & $173.3^{\mathrm{d}}$ & $183.5^{\text {def }}$ & $17.0^{\mathrm{bc}}$ & $25.7^{\mathrm{bc}}$ & $32.4^{\mathrm{b}}$ \\
\hline $\mathrm{T}_{14}: 4.5 \mathrm{t} /$ ha $\mathrm{PL}+\mathrm{N}_{40} \mathrm{P}_{30} \mathrm{~K}_{50} \mathrm{~kg}$ /ha & $82.0^{c}$ & $163.7^{\mathrm{d}}$ & $174.3^{\text {de }}$ & $16.7^{\mathrm{b}}$ & $24.7^{\mathfrak{b}}$ & $36.0^{\mathrm{bc}}$ \\
\hline $\mathrm{T}_{15}: 4.5 \mathrm{t} / \mathrm{ha} \mathrm{PL}+\mathrm{N}_{80} \mathrm{P}_{60} \mathrm{~K}_{100} \mathrm{~kg}$ ha & $65.3^{\mathrm{bc}}$ & $173.0^{\mathrm{d}}$ & $185.7^{\mathrm{def}}$ & $16.0^{\mathrm{b}}$ & $27.0^{c}$ & $40.5^{\mathrm{bc}}$ \\
\hline $\mathrm{T}_{16}: 4.5 \mathrm{t}$ /ha PL + $\mathrm{N}_{120} \mathrm{P}_{90} \mathrm{~K}_{150} \mathrm{~kg}$ /ha & $75.0^{\mathrm{bc}}$ & $194.0^{\mathrm{de}}$ & $204.3^{\mathrm{f}}$ & $17.0^{\mathrm{bc}}$ & $26.67^{c}$ & $44.8^{\mathrm{bc}}$ \\
\hline LSD at $5 \%$ & 16.0 & 21.58 & 21.86 & 1.62 & 4.64 & 4.74 \\
\hline
\end{tabular}

RDF= Recommended dose of fertilizer. $\quad \mathrm{PL}=$ Poultry litter compost. DAS = Days after sowing. ${ }^{\text {abc }}$ Data bearing different superscripts in the same column differ significantly at $5 \%$ level.

different from $T_{9}, T_{10}, T_{13}$ and $T_{15}$ treatment at 60 days after sowing (DAS). Similar results were observed in the number of leaf/plant with a little difference, i.e., with the increase in sowing time single organic or chemical and (chemical plus organic) were only significantly $(p<0.05)$ different from the control treatment. The highest combination of 
both poultry litter compost and chemical fertilizers growth of sunflower plant. Application of poultry manure compost and NPK fertilizer significantly increased the cabbage head length, plant height, stem girth, leaf number and leaf area ${ }^{(14)}$.

Leaf area and leaf area index: Effects of poultry litter compost and NPK fertilizers on leaf area and leaf area index of sunflower plants are shown in Table 2. Similar to plant height and number of leaves of sunflower plant leaf area and leaf area index were significantly $(p<0.05)$ higher in the treatment of single organic or combined (organic plus inorganic) than the control treatment. But the pattern of treatment effects were different from plant height and number of leaf/plant. Leaf area $\left(376.4 \mathrm{~cm}^{2}\right)$ and leaf area index (13.61) were also highest in the $\mathrm{T}_{16}\left(4.5\right.$ ton $\mathrm{PL}+\mathrm{N}_{120} \mathrm{P}_{90} \mathrm{~K}_{150} \mathrm{~kg}$ ha) treatment. Uddin et al. (5) also reported that height, leaf number, leaf area in arum were achieved highest significantly $(p<0.05)$ in the combined application of decomposed poultry litter compost and nitrogen.

Table 2. Influence of poultry litter and NPK fertilizers on leaf area $\left(\mathrm{cm}^{2}\right)$ and leaf area index of sunflower plant.

\begin{tabular}{|c|c|c|c|c|c|c|}
\hline \multirow[t]{2}{*}{ Treatments } & \multicolumn{3}{|c|}{ Leaf area $\left(\mathrm{cm}^{2}\right)$} & \multicolumn{3}{|c|}{ Leaf area index } \\
\hline & 30 DAS & 60 DAS & 90 DAS & 30 DAS & 60 DAS & 90 DAS \\
\hline T1: Control (-PL and - NPK) & $102.4^{\mathrm{a}}$ & $111.3^{a}$ & $69.0^{\mathrm{a}}$ & $1.35^{\mathrm{a}}$ & $0.98^{a}$ & $1.40^{\mathrm{a}}$ \\
\hline $\mathrm{T}_{2}: 1.5 \mathrm{t} / \mathrm{ha} \mathrm{PL}$ (50 \% RDF) & $121.3^{\mathrm{a}}$ & $93.7^{\mathrm{a}}$ & $124.0^{\mathrm{b}}$ & $1.93^{\mathrm{a}}$ & $1.94^{\mathrm{a}}$ & $3.01^{\mathrm{a}}$ \\
\hline $\mathrm{T}_{3}: 3$ t/ha PL (100 \% RDF) & $155.2^{\mathrm{a}}$ & $94.3^{\mathrm{a}}$ & $190.5^{c}$ & $2.06^{\mathrm{a}}$ & $1.92^{\mathrm{a}}$ & $4.55^{\mathrm{b}}$ \\
\hline $\mathrm{T}_{4}: 4.5$ t/ha PL (150 \% RDF) & $105.8^{\mathrm{a}}$ & $114.6^{\mathrm{a}}$ & $212.3^{\mathrm{d}}$ & $1.59^{a}$ & $2.3^{a}$ & $6.10^{\mathrm{b}}$ \\
\hline $\mathrm{T}_{5}: \mathrm{N}_{40} \mathrm{P}_{30} \mathrm{~K}_{50} \mathrm{~kg}$ ha (50\% RDF) & $188.7^{\mathrm{a}}$ & $101.7^{\mathrm{a}}$ & $224.5^{\mathrm{e}}$ & $2.97^{\mathrm{b}}$ & $2.24^{\mathrm{a}}$ & $6.32^{\mathrm{b}}$ \\
\hline $\mathrm{T}_{6}: \mathrm{N}_{80} \mathrm{P}_{60} \mathrm{~K}_{100} \mathrm{~kg} / \mathrm{ha}(100 \% \mathrm{RDF})$ & $190.2^{\mathrm{a}}$ & $152.7^{\mathrm{a}}$ & $262.4^{\mathrm{f}}$ & $3.09^{\mathrm{b}}$ & $3.6^{b}$ & $8.50^{c}$ \\
\hline $\mathrm{T}_{7}: \mathrm{N}_{120} \mathrm{P}_{90} \mathrm{~K}_{150} \mathrm{~kg}$ ha $(150 \% \mathrm{RDF})$ & $207.3^{\mathrm{b}}$ & $177.3^{\mathrm{a}}$ & $274.0^{\mathrm{g}}$ & $3.79^{\mathrm{b}}$ & $4.49^{\mathrm{b}}$ & $8.65^{c}$ \\
\hline $\mathrm{T}_{8}: 1.5 \mathrm{t} / \mathrm{ha} \mathrm{PL}+\mathrm{N}_{40} \mathrm{P}_{30} \mathrm{~K}_{50} \mathrm{~kg}$ /ha & $155.0^{\mathrm{a}}$ & $156.3^{\mathrm{a}}$ & $278.6^{\mathrm{g}}$ & $2.44^{\mathrm{a}}$ & $4.29^{\mathrm{b}}$ & $8.44^{c}$ \\
\hline $\mathrm{T}_{9}: 1.5 \mathrm{t} /$ ha $\mathrm{PL}+\mathrm{N}_{80} \mathrm{P}_{60} \mathrm{~K}_{100} \mathrm{~kg} / \mathrm{ha}$ & $150.7^{\mathrm{a}}$ & $162.3^{\mathrm{a}}$ & $294.5^{\mathrm{h}}$ & $2.32^{\mathrm{a}}$ & $3.44^{\mathrm{b}}$ & $9.75^{c}$ \\
\hline $\mathrm{T}_{10}: 1.5 \mathrm{t} / \mathrm{ha} \mathrm{PL}+\mathrm{N}_{120} \mathrm{P}_{90} \mathrm{~K}_{150} \mathrm{~kg} / \mathrm{ha}$ & $217.5^{\mathrm{b}}$ & $298.0^{\mathrm{b}}$ & $340.0^{\mathrm{i}}$ & $3.62^{\mathrm{b}}$ & $8.15^{c}$ & $12.40^{\mathrm{d}}$ \\
\hline $\mathrm{T}_{11}: 3 \mathrm{t} /$ ha $\mathrm{PL}+\mathrm{N}_{40} \mathrm{P}_{30} \mathrm{~K}_{50} \mathrm{~kg} / \mathrm{ha}$ & $104.0^{\mathrm{a}}$ & $132.2^{\mathrm{a}}$ & $282.0 \mathrm{~g}$ & $2.36^{\mathrm{a}}$ & $3.16^{\mathrm{a}}$ & $10.02^{\mathrm{cd}}$ \\
\hline $\mathrm{T}_{12}: 3 \mathrm{t}$ /ha $\mathrm{PL}+\mathrm{N}_{80} \mathrm{P}_{60} \mathrm{~K}_{100} \mathrm{~kg}$ /ha & $214.7^{\mathrm{b}}$ & $150.7^{a}$ & $310.5^{j}$ & $3.56^{\mathrm{b}}$ & $3.53^{\mathrm{b}}$ & $8.30^{\mathrm{cd}}$ \\
\hline $\mathrm{T}_{13}: 3 \mathrm{t}$ /ha PL+ $\mathrm{N}_{120} \mathrm{P}_{90} \mathrm{~K}_{150} \mathrm{~kg}$ ha & $284.0^{\mathrm{ab}}$ & $231.0^{\mathrm{b}}$ & $275.0 \mathrm{~g}$ & $4.78^{\mathrm{bc}}$ & $6.03^{d}$ & $7.70^{c}$ \\
\hline $\mathrm{T}_{14}: 4.5 \mathrm{t} / \mathrm{ha} \mathrm{PL}+\mathrm{N}_{40} \mathrm{P}_{30} \mathrm{~K}_{50} \mathrm{~kg} / \mathrm{ha}$ & $164.5^{\mathrm{ab}}$ & $127.0^{\mathrm{a}}$ & $360.5^{\mathrm{k}}$ & $2.76^{\mathrm{a}}$ & $3.02^{\mathrm{a}}$ & $5.52^{\mathrm{b}}$ \\
\hline $\mathrm{T}_{15}: 4.5 \mathrm{t} / \mathrm{ha} \mathrm{PL}+\mathrm{N}_{80} \mathrm{P}_{60} \mathrm{~K}_{100} \mathrm{~kg}$ /ha & $192.3^{\mathrm{ab}}$ & $167.7^{a}$ & $302.0^{1}$ & $2.71^{\mathrm{a}}$ & $4.58^{\mathrm{b}}$ & $9.85^{c}$ \\
\hline $\mathrm{T}_{16}: 4.5 \mathrm{t} / \mathrm{ha} \mathrm{PL}+\mathrm{N}_{120} \mathrm{P}_{90} \mathrm{~K}_{150} \mathrm{~kg} / \mathrm{ha}$ & $248.3^{\mathrm{ab}}$ & $236.7^{b}$ & $376.4^{\mathrm{m}}$ & $4.33^{\mathrm{bc}}$ & $6.35^{\mathrm{d}}$ & $13.61^{\mathrm{d}}$ \\
\hline LSD at $5 \%$ & 97.52 & 85.57 & 5.74 & 1.60 & 2.36 & 2.61 \\
\hline
\end{tabular}

RDF= Recommended dose of fertilizer. PL= Poultry litter compost. DAS = Days after sowing. ${ }^{\text {abc }}$ Data bearing different superscripts in the same column differ significantly at $5 \%$ level.

Dry weight of root and stem: Effects of poultry litter compost and NPK fertilizers on dry matter and seed yield of sunflower plants are shown in Table 3. In this case, result is 
different from those of plant height, leaf number, leaf area and leaf area index. Dry weights of root, stem and leaf are significantly $(p<0.05)$ higher in $T_{6}, T_{7}, T_{13}, T_{14}, T_{15}$ and $\mathrm{T}_{16}$ than the control treatment. In case of total dry matter yield greater value is found in the $T_{6}$ and $T_{7}$ for single doses of inorganic fertilizer and in the $T_{10}, T_{13}, T_{15}$ and $T_{16}$ for combined doses of fertilizer (organic plus inorganic). Among the treatments, $\mathrm{T}_{16}$ treatment shows significantly ( $\mathrm{p}<0.05)$ highest result, i.e., dry weights of root $(12.66 \mathrm{~g})$, shoot $(61.57 \mathrm{~g})$, leaf $(21.47 \mathrm{~g})$, petiole $(8.7 \mathrm{~g})$, inflorescence (28.6) and total dry matter yield $(134.0 \mathrm{~g})$ than the other treatments. Application of poultry manure significantly increased dry matter production/plant of sunflower(15).

Dry weight of leaf and petiole: The results showed that identical variation was observed over the control in all the treatments except the treatments where highest rate of poultry litter with fertilizers were applied. Similar significant effect was observed in treatments to increase leaf weight/plant. Weight of petiole/plant increased in the treatments receiving higher rates of chemical fertilizers and poultry litter. However, the increase in petiole weight/plant remained identical. The highest weight of leaf/plant $(21.47 \mathrm{~g})$ and petiole/plant (8.7 g) were observed in $\mathrm{T}_{16}\left(4.5 \mathrm{t}\right.$ PL/ha $+\mathrm{N}_{120} \mathrm{P}_{90} \mathrm{~K}_{150} \mathrm{~kg} / \mathrm{ha}$ ) treatment. Gain ${ }^{(6)}$ also reported that the highest total dry matter production was found significantly with (RDF 75\% from PL plus 25\% RDF).

Dry weight of inflorescence: Dry weight of inflorescence/plant showed the similar pattern in variation of weight of petiole/plant. Lower rates of poultry litter alone were not significant to increase the weight of inflorescence/plant. Weight of inflorescence/plant increased significantly due to application of poultry litter with chemical fertilizers in their higher rates of combination. The range of weight of inflorescence varied from 5.4 to $32.6 \mathrm{~g} /$ plant. The highest weight was recorded in $\mathrm{T}_{13}$ treatment.

Total dry matter yield: Total dry matter yield increased notably with increasing rate of poultry litter and chemical fertilizers either applied alone or together. Production of dry matter was relatively higher in combined treatments than the individual applications of poultry litter and chemical fertilizers. Maximum yields of dry matter were $134.0 \mathrm{~g} /$ plant and $7.0 \mathrm{t} / \mathrm{ha}$ and recorded in the $\mathrm{T}_{16}$ treatment. Highest total dry matter production was found significantly with combined doses (organic and inorganic) of fertilizers ${ }^{(6)}$.

Diameter of inflorescence: Diameter of inflorescence of sunflower increased variably over the control and was statistically significant (Table 3). Poultry litter alone and lower doses of fertilizer showed no significant increase in diameter of inflorescence over the control. Lower dose of fertilizer even with the higher dose of poultry litter also showed similar effect. The higher doses of fertilizers with all levels of poultry litter showed better results and were significant but the variation between them were not significant. The highest diameter of inflorescence $(54.0 \mathrm{~cm})$ was recorded in the $\mathrm{T}_{13}$ treatment. 
EFFECTS OF POULTRY LITTER COMPOST AND CHEMICAL FERTILIZERS

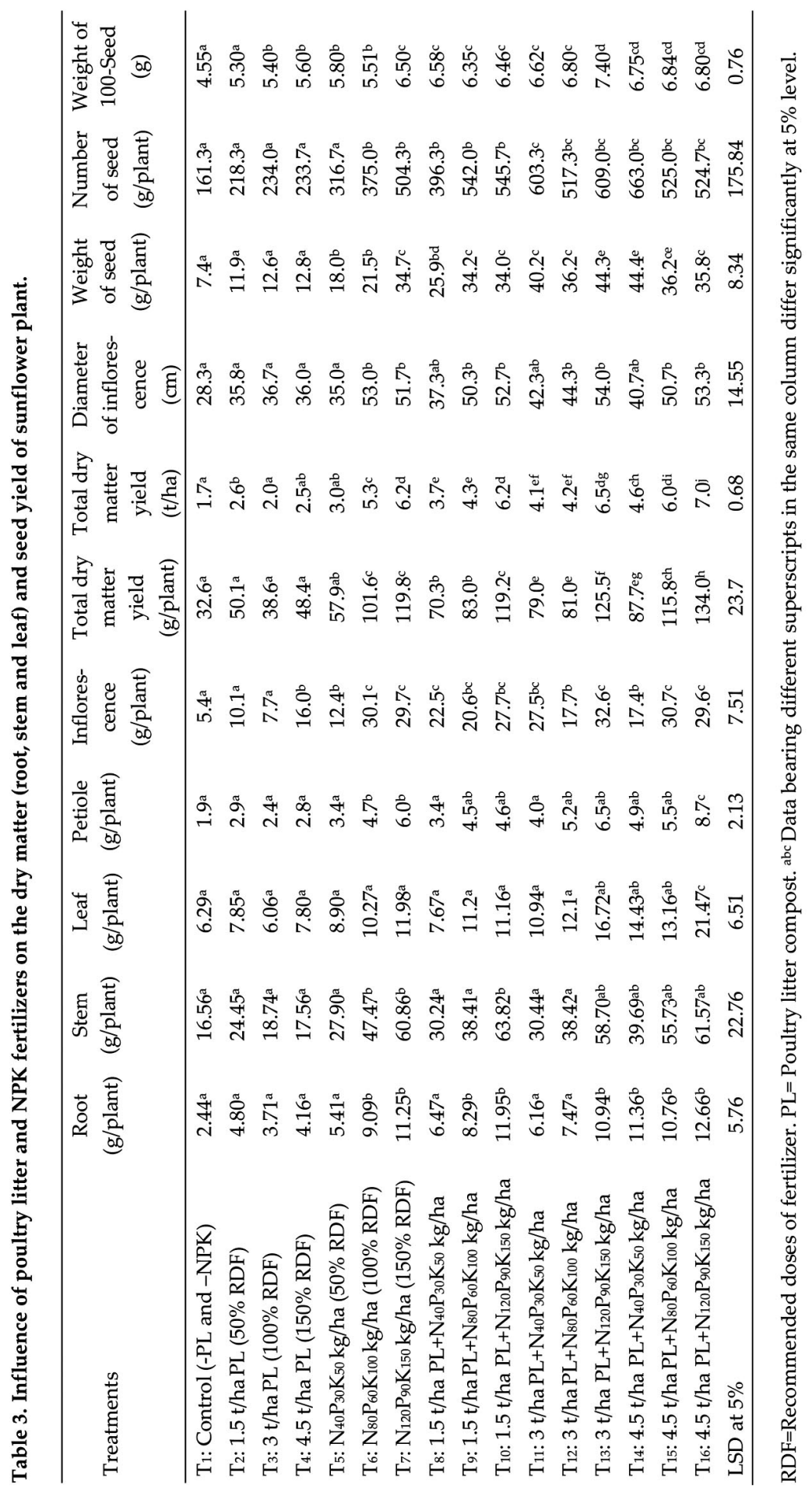


Weight of seed and number of seed: Dry weight of seed/plant and number of seed plant ${ }^{-1}$ increased significantly $(\mathrm{p}<0.05)$ due to influence of poultry litter and chemical fertilizers over the control (Table 3). The result showed that both the parameters increased with increasing doses of poultry litter and chemical fertilizer except the influence of poultry litter alone. Variation in weight of seed/plant and number of seeds/plant were not significant at lower levels of poultry litter and chemical fertilizers. However, an opposite trend was observed in the treatments of higher combinations. The maximum weight of seed plant (44.4 g) and number of seeds/plant (663 g) was observed in the same treatment poultry litter and chemical fertilizers in the $\mathrm{T}_{13}$ and $\mathrm{T}_{14}$ treatments.

Weight of 100-seed: Poultry litter and chemical fertilizers applied in different combinations showed a significant $(\mathrm{p}<0.05)$ increase in weight of 100 seed grains of sunflower when compared with the control (Table 3). All the treatments caused a significant increase in weight of 100 -seed grains of sunflower as compared to control but the variations among the treatments were not significant. The increase in weight of 100seed grains generally increased with rates of poultry litter and fertilizers. The highest weight of 100-seed grains $(7.4 \mathrm{~g})$ was observed in $\mathrm{T}_{13}$ treatment.

The results of this experiment revealed that single inorganic or organic fertilizer did not give significantly higher results, but combined application (inorganic + organic) of fertilizers gave highest values of results; among them $T_{9}, T_{10}, T_{13}$ and $T_{16}$ treatments may be considered to grow sunflower plant. This might be applied to achieve better agronomic and yield parameters of sunflower plants in southern coastal edaphic conditions of Bangladesh.

\section{References}

1. Shogi-Kalkhoran S, A Ghalavand, SMA Modarres-Sanavy, A Mokhtassi-Bidgoli and A Akbari 2013. Integrated fertilization systems enhance quality and yield of sunflower (Helianthus annus L.). J. Agric. Sci. Tech. 15: 1343-1352.

2. Khakwani AZ, S Noor, M Sadiq, IU Awan, M Munir, MS Baloch, G Farullah and I Bakhash 2014. Impact of plant densities and NPK fertilization on growth and optimum economic return of sunflower. Sarhad J. Agric. 30(2): 157-164.

3. Rasool FU, B Hassan and IA Jahangir 2013. Growth and yield of sunflower (Helianthus annus L.) as influenced by nitrogen, sulfur and farmyard manure under temperate conditions. SAARC J. Agril. 11(1): 81-89.

4. Akbari P, A Ghalavand, AM Modarres Sanavy and MA Alikhani 2011. The effect of biofertilizers, nitrogen fertilizer and farmyard manure on grain yield and seed quality of sunflower (Helianthus annus L.). J. Agril. Tech. 7(1): 173-184.

5. Uddin MK, J sultana, M Alauddin, MH Rahman, M Akhter, AP Rodrigues, AHMZ Ali and MK Rahman 2018. Effects of decomposed poultry litter, nitrogen and phosphorus on growth and micronutrient content of arum (Colocasia esculentus L.). J. Biodivers. Conserve. Bioresour. Manag. 4(1): 11-18. 
6. Gani MN 2014. Impact of Poultry Litter on Soil Properties and Production of Jute. Unpublished Ph D Thesis, Department of Soil, Water and Environment. University of Dhaka, Bangladesh, Dhaka-1000. Bangladesh.

7. Kulkarni SS, R Babu and BT Pujari 2002. Growth, yield and yield parameters of sunflower as influenced by organic manures, biofertilizers and micronutrients under irrigation. Karnataka J. Aric. Sci. 15(2): 253-255.

8. Boateng AS, J Zickermann and M Kornaharens 2006. Effect of poultry manure on growth and yield of maize. West Afr. J. Appl. Ecol.

9. Walkley A and IA Black. 1934. An examination of Degtjareff method for determining soil organic matter and proposed modification for the chromic acid titration method. Soil Sci. 37: 29-38.

10. Marr IL and MS and Cresser 1983. The lithosphere. In: Environmental Chemical Analysis. Blackie and Son, UK. pp. 155-182.

11. Murphy J and JP Riley 1962. A modified single solution method for the determination of phosphate in natural waters. Anal. Chim. Acta 27: 31-36.

12. Bouyoucos GJ 1962. Hydrometer method improved for making particle size analysis of soils. Agron. J. 54: 461-465.

13. BARC (Bangladesh Agricultural Research Council) 2012. Fertilizer Recommendation Guide. BARC Soils Publication No. 49. Peoples Press and Publications, Purana Palton, Dhaka. pp. 112.

14. Moyin-Jesu, E.L. 2019. Use of different organic fertilizers on soil fertility improvement, growth and yield of cabbage (Brassica oleraceae L.). Int. J. Rec. Org. Waste Agric. 4(291): 1-13

15. Esmaeilian Y, AR Sirousmerh, MR Asghripour and E Amiri 2012. Comparison of sole and combined nutrient application on yield and biochemical composition of sunflower under water stress. Int. J. Appl. Sci. Tech. 2(3): 214-220.

(Manuscript received on 22 January, 2020; revised on 21 August, 2020) 